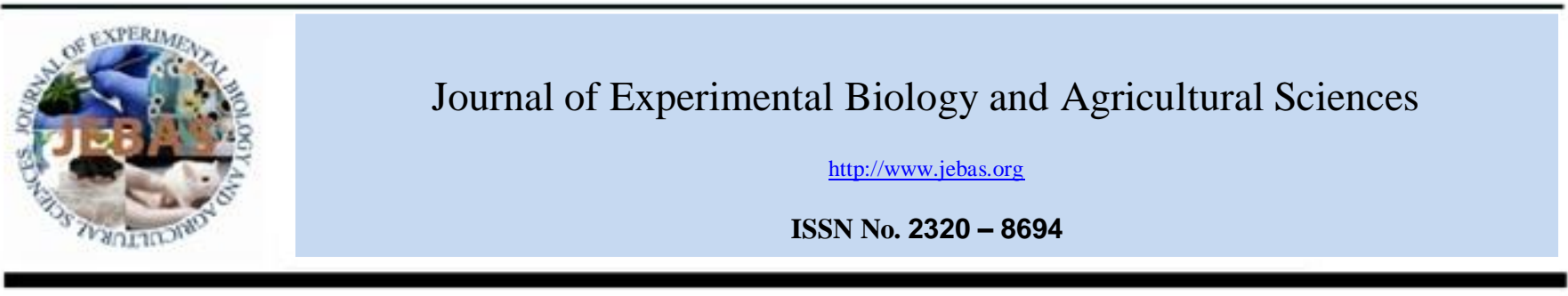

\title{
NUTRITIONAL AND BIOCHEMICAL EFFECTS OF ASPARTAME INTAKE IN RATS UNDER AN EXPERIMENTAL DIET
}

\section{Flavio Martinez-Morales ${ }^{1}$, Enrique Maldonado-Cervantes ${ }^{2}$, Mario Alberto Isiordia-Espinoza ${ }^{3}$ and Othoniel Hugo Aragon-Martinez ${ }^{1}$ *}

${ }^{1}$ Department of Pharmacology, School of Medicine, University of San Luís Potosí, San Luís Potosí, S.L.P., México
${ }^{2}$ Multidisciplinary Academic Unit Middle Zone, University of San Luís Potosí, Rioverde, S.L.P., México
${ }^{3}$ Department of Pharmacology, School of Odontology, University of Baja California, Mexicali, Baja California, México

Received - April 13, 2015; Revision - May 11, 2015; Accepted - June 25, 2015

Available Online - June 26, 2015

DOI: http://dx.doi.org/10.18006/2015.3(3).298.306

KEYWORDS
Aspartame
Coconut fat
Cardiovascular factors
Body weight
Blood pressure

* Corresponding author

E-mail: hugo.aragon@uaslp.mx (Othoniel Hugo Aragon-Martinez)

Peer review under responsibility of Journal of Experimental Biology and Agricultural Sciences.

Production and Hosting by Horizon Publisher (www.myvision.webs.com/horizon.html)

All rights reserved.

\begin{abstract}
The present study evaluates the effect of aspartame intake in rats under a diet mimicking the trends of fat consumption in the society. The composition of the experimental diet was within the recommended human limits except the saturated fat amount supplying from coconut fat. Rats under the experimental diet showed an increase in the body weight, transitory increase in the blood pressure and in plasma values of glucose and triglycerides alongside a transitory reduction in plasma urea versus the standard group. Rats under the experimental diet plus aspartame intake $(54.8 \pm 7.3 \mathrm{mg} / \mathrm{kg}$ bw/day) did not show any increase of body weight and in plasma values of glucose and triglycerides while showed an improvement in the plasma value of urea with respect the group under only the experimental diet. However, the aspartame group showed a more maintained increase of blood pressure. In conclusion, experimental diet produces negative effects on cardiovascular risk factors of the rats while the aspartame intake under the experimental feeding had mixed effects on the cardiometabolic factors of the animals.
\end{abstract}

All the article published by Journal of Experimental

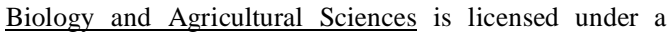
Creative Commons Attribution-NonCommercial 4.0 International License Based on a work at www.jebas.org.

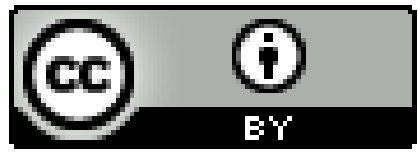




\section{Introduction}

Aspartame a synthetic nonnutritive sweetener is a widespread component in the current human diet. This sweetener employed for diverse proposes such as the reduction in sugar consumption, decrease of caloric intake and to maintain or lose body weight keeping the palatability of the food. Aspartame approved as a sweetening agent and a flavor enhancer in more than 90 countries and has been added to over 6000 products worldwide (Butchko et al., 2002; Magnuson et al., 2007). The acceptable daily intake for aspartame in humans was established at 40 or $50 \mathrm{mg} / \mathrm{kg}$ of body weight (bw) according to the European Union's Scientific Committee on Food or the U.S. Food and Drug Administration, respectively (Magnuson et al., 2007).

Premarketing and postmarketing evaluations of aspartame demonstrated their safe use for human consumption (Butchko et al., 2002; Magnuson et al., 2007). However, other studies have been demonstrated that the consumption of aspartame may cause deleterious effects such as hepatocellular injury, carcinogenic effects and systemic hypertension (Roberts, 2004; Soffritti et al., 2006; Gombos et al., 2007; Abhilash et al., 2011).

In the same manner, ubiquitous components of the food supply such as fats, sugars and proteins have physiological functions in the body (Joint WHO/FAO/UNU Expert Consultation, 2002; Johnson et al., 2009; Nettleton et al., 2013). However, changes in the dietary and lifestyle patterns contribute to the causal factors underlying the rapidly increase of the worldwide burden of chronic diseases including obesity, diabetes, cardiovascular disease, hypertension, stroke and some types of cancer. For example, intake of dietary fats has a remarkable increase in the world over the past three decades where North America and Europe have the high consumption amounts (Joint WHO/FAO Expert Consultation, 2003). Consequently, the Joint World Health Organization / Food and Agricultural Organization (WHO/FAO) recommends a human consumption of saturated fat of $<10 \%$, added sugar of $<10 \%$ and protein of $10-15 \%$ of energy alongside other recommendations to prevent the diet-related diseases (Joint WHO/FAO Expert Consultation, 2003; FAO Expert Consultation, 2010).

A study assaying the aspartame intake under a similar pattern of the society feeding relating to the WHO/FAO recommended limits has not been reported (Frey, 1976; Knopp et al., 1976; Ishii et al., 1981; Stegink et al., 1983; Shahangian et al., 1984; Stegink, 1987; Colagiuri et al., 1989; Gupta et al., 1989; Butchko et al., 2002; Gougeon et al., 2004; Roberts, 2004; de la Hunty et al., 2006; Soffritti et al., 2006; Gombos et al., 2007; Magnuson et al., 2007; Soffritti et al., 2007; Roberts, 2008; Anton et al., 2010; Abhilash et al., 2011; Aune, 2012; Schernhammer et al., 2012; Feijó et al., 2013; Palmnäs et al., 2014). Therefore, the aim of this study was to evaluate the nutritional and biochemical effects of aspartame in Wistar rats consuming a fat plus sucrose enriched diet relating to the WHO/FAO values.

\section{Materials and Methods}

\subsection{Animals and diets}

After one week of acclimatization, thirteen-week-old male Wistar rats were randomly divided in the standard (S) group and experimental (E) group. The $S$ group $(n=6)$ had free access to standard pellets (Rodent Laboratory Chow 5001, PMI Nutrition Int'1, LLC, Brentwood, MO) while the E group $(\mathrm{n}=12)$ fed ad libitum coconut fat and sucrose supplemented standard pellets for 22 weeks. The caloric density for the $\mathrm{S}$ diet was $3.19 \mathrm{kcal} / \mathrm{g}$ with $28.9 \%$ of the energy (\%E) from protein, $58.4 \% \mathrm{E}$ of total carbohydrates, $12.7 \% \mathrm{E}$ of total fat and $4.4 \% \mathrm{E}$ of saturated fat while the E diet was $3.99 \mathrm{kcal} / \mathrm{g}$ with $15.4 \% \mathrm{E}$ of protein, $57.0 \% \mathrm{E}$ of total carbohydrates, $10.3 \% \mathrm{E}$ of free sucrose, $27.7 \% \mathrm{E}$ of total fat and $15.9 \% \mathrm{E}$ of saturated fat. The nutritional information of diets was obtained from the supplier and food analysis in the Center of Investigation and Postgrade Studies (CIEP) from the University of San Luís Potosí. The animals were housed in individual acrylic cages with free access to water under a controlled humidity $(65-70 \%)$ and temperature $\left(24 \pm 2{ }^{\circ} \mathrm{C}\right)$, maintained on a $12 \mathrm{~h}$ light and dark cycle. The $\mathrm{E}$ group was divided into two groups in the week 11. The first group maintained the original condition while the second group drank a solution of aspartame instead water and consumed the experimental diet (EA group, $n=6$ ). The $E$ pellets were prepared weekly and stored at $4^{\circ} \mathrm{C}$. The aspartame solution was prepared daily and maintained at room temperature. The animals were handled according to the National Research Council Guide for the Care and Use of Laboratory Animals (2011) and the study was approved by the Research Ethics Committee of the host institution.

\subsection{Nutritional measurements and blood pressure recording}

The animals were weighed weekly at the morning time. Food intake was calculated daily by the subtraction of the remaining amount from the supplied amount of the diet taking account the body weight of the animal. In the same manner, the aspartame intake was calculated daily using the concentration of the aspartame solution, the supplied and remaining volume of the solution and the body weight of the animal. The daily caloric intake was obtained from the multiplication of the food intake with the caloric density of the diet. These measurements were taken during the weeks 1 to 22 . After warming rats for 20 minutes on a $37{ }^{\circ} \mathrm{C}$ chamber, the systolic and diastolic blood pressures were recorded in completely conscious rats using the Non-Invasive Blood Pressure System for Rodents (Panlab s.l., Barcelona, Spain) during the weeks 10, 14, 16, 18, 20 and 22. At the end of the study, the mesenteric, epididymal and perirenal adipose tissues were weighed after the sacrifice of each animal. 
2.3 Biochemical measurements

One milliliter of blood of each rat in fast was drawn from the tail vein using a Heparin-coated needle during the weeks 10 , 14, 18 and 22. The blood sample was centrifuged at 12,100 rpm for $10 \mathrm{~min}$ at $10^{\circ} \mathrm{C}$ in a Sorvall RMC 14 Refrigerated Microcentrifuge (Sorvall Products, L.P., CT, USA). Then, the plasma was collected and it was stored at $-80^{\circ} \mathrm{C}$ until use. In the following day of the blood sampling, each rat was placed in a metabolic cage for the collection of $1 \mathrm{~mL}$ of urine sample and recording of the 24-urinary volume. The urine sample was centrifuged using the same blood procedure and the supernatant was stored at $-80^{\circ} \mathrm{C}$ until use. Glucose, triglycerides and urea were measured in each plasma sample while the creatinine was measured in urine and plasma samples using the automated analyzer Vitalab Selectra Junior ( ${ }^{\circledR}$ (Vital Scientific NV, Dieren, the Netherlands). All biochemical assays were done according to the Official Mexican Normativity for clinical laboratories (NOM-166-SSA1-1997). The creatinine clearance was calculated employing the formula used by Hazelholff et al. (2012).

\subsection{Statistical analysis}

The data is presented as the mean only or mean \pm standard deviation (SD) and was analyzed employing the two-way ANOVA with Bonferroni post test. Only the information from adipose tissue was analyzed using the one-way ANOVA with Tukey post test. A P value of $<0.05$ was considered statistically significant. GraphPad Prism 5 software (San Diego, CA, USA) was used for statistical analysis.

\section{Results}

The results of the study revealed that aspartame intake in the group EA was $54.8 \pm 7.3 \mathrm{mg} / \mathrm{kg}$ of the bw/day. The nutritional parameters of animal groups are shown in Figure 1. The food consumption was lower in $\mathrm{E}$ and $\mathrm{EA}$ groups than the $\mathrm{S}$ intake starting in the week 4 (Figure. 1A). However, the caloric intake in the $\mathrm{E}$ group was superior to $\mathrm{S}$ data from the week 1 until the week 8. After this week, the caloric intake was similar in all groups (Figure. 1B). The body weight information showed higher values in the $\mathrm{E}$ group than the $\mathrm{S}$ and EA data after the week 10 (Figure. 1C). However, the values from the adipose tissue did not have statistical significant difference between these groups at the week 22 (Figure. 1D). The Figure. 2 shows the recording of blood pressure of the animals. The $\mathrm{E}$ diet caused an increase of the systolic blood pressure in the rats only in the week 16 versus the S values. Meanwhile, the EA feeding increased the systolic blood pressure in the rats in the weeks 14,16 and 18 with respect to $S$ and $E$ values (Figure. 2A). The diastolic blood pressure was only increased in the EA group versus $\mathrm{S}$ data in the week 14 (Figure. 2B). The E diet caused an increase of the glucose and triglycerides alongside a reduction of the urea in the plasma samples from rats between the weeks 10 and 18 versus the $\mathrm{S}$ data. The EA group had a reduction of the plasma urea versus the $S$ data without other significant changes (Figure. 3A, B and C). Finally, the plasma creatinine was reduced in the EA group versus the $\mathrm{S}$ and $\mathrm{E}$ values (Figure. $4 \mathrm{~A}$ ). The remainder of values in all groups did not have significant changes (Figure. $4 \mathrm{~B}$ and $\mathrm{C}$ ).

\section{Discussion and conclusions}

All of data from the $\mathrm{S}$ group were in accordance with the literature normal values (Olmsted et al., 1951; Fisher, 1965; López-Varela et al., 1995; Zulet et al., 1999; Palm \& Lundblad, 2005; Buettner et al., 2006; Romestaing et al., 2007; Jhonson-Delaney, 2008; Amin et al., 2011; Hazelhoff et al., 2012; Moura et al., 2012; Poudyal et al., 2012). However, the trend to reduced intakes of food and calories in the $S$ group through the time of the study were contradictory to previous normal data (Buettner et al., 2006; Romestaing et al., 2007; Amin et al., 2011). This difference may be explained by the declined energy intake due to increasing age (Thomas et al., 2002) because the present study used older animals than prior studies. This study used adult animals because the highest consumption of aspartame in humans is by individuals aged 25 to 59 (FSANZ, 2004).

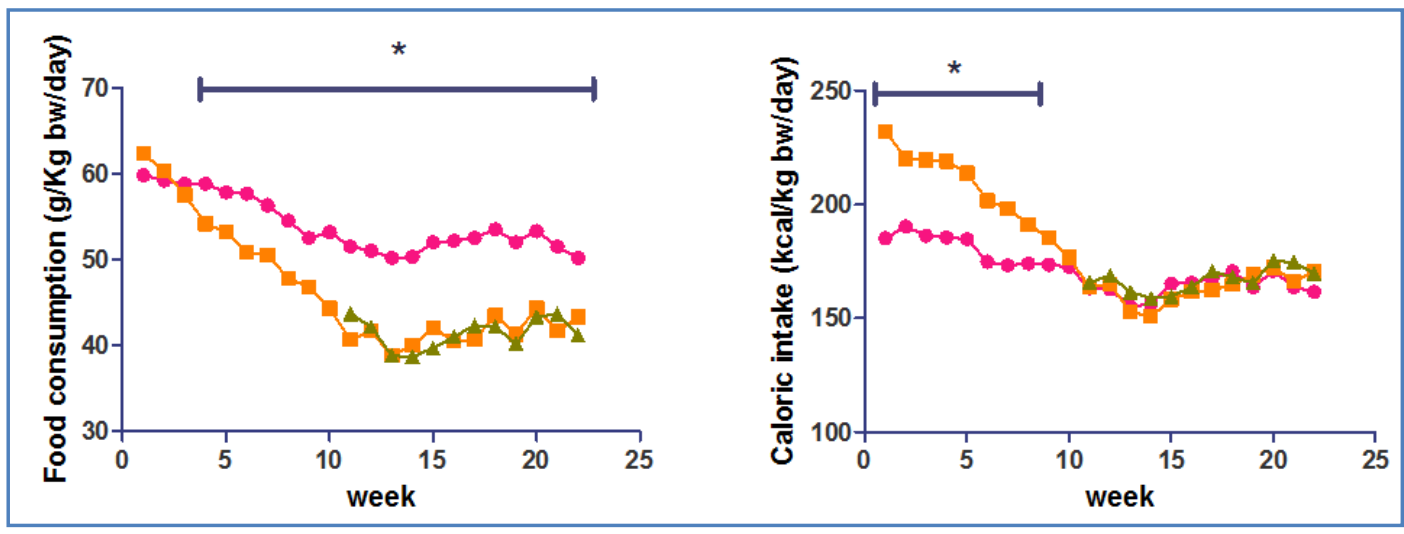

A 


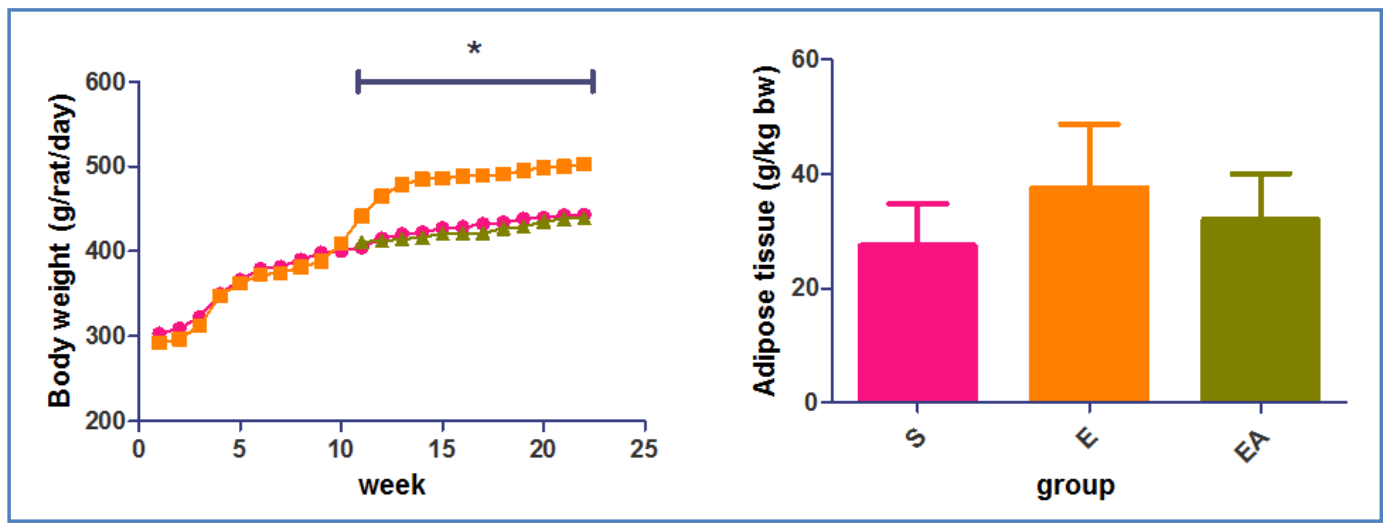

C

$\mathrm{D}$

Figure 1 Nutritional status of animals. The differences $(*)$ had $\mathrm{P}$ values of $<0.01$ versus $\mathrm{S}$ group $(\mathrm{A})$, of $<0.05$ versus $\mathrm{S}$ group (B), of $<0.001$ versus E group (C) or not showed significant changes (D). Standard group (S, pink circle), experimental group (E, oran ge square) and experimental plus aspartame group (EA, brown triangle). bw; body weight.

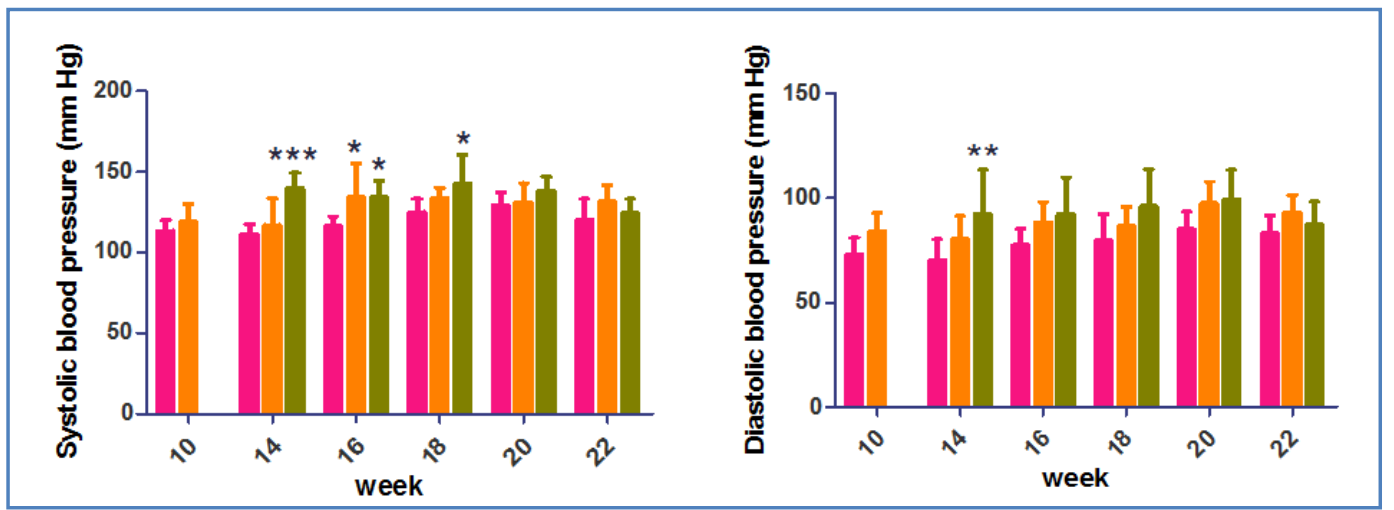

A

B

Figure 2 Blood pressures of animals. The differences $(*)$ and $(* * *)$ had $\mathrm{P}$ values of $<0.05$ versus $\mathrm{S}$ group and $<0.001$ versus $\mathrm{S}$ group plus $<0.01$ versus E group, respectively (A). The difference $(* *)$ had a $\mathrm{P}$ value of $<0.01$ versus $\mathrm{S}$ group $(\mathrm{B})$. Standard group (pink bar), experimental group (orange bar) and experimental plus aspartame group (brown bar).

Coconut fat and sucrose were incorporated into present experimental chow. The final composition of the $\mathrm{E}$ diet was within the WHO/FAO recommended limits for humans except the saturated fat amount, where the source of this excess was the coconut fat. In this manner, the $\mathrm{E}$ diet caused a reduction in the food ingestion, similar caloric intake, slow increase in the body weight, transient changes in plasma values (urea, triglycerides and glucose) and blood pressure, and unalterable parameters of creatinine in the rats versus the $S$ data. In present study $\mathrm{E}$ information is in accordance with the unchanged values of creatinine and plasma modifications of triglycerides and urea in animals under a coconut fat diet (Cera et al., 1990; Buettner et al., 2006; Buettner et al., 2007).

In this case, the reduction of urea in plasma is also probably due to low amount of protein from the consumed diet due to the reduced food consumption versus the $\mathrm{S}$ data (Hosten, 1990).
On the other hand, the E data are contrary to the fast weight gain and on set of hyperphagia observed in prior coconut fat or sucrose studies (Buettner et al., 2006; Buettner et al., 2007; Amin et al., 2011; Cahova et al., 2012), increased values of creatinine and urea in serum due to a high sucrose diet (Amin et al., 2011) and unaltered sera values of glucose in previous coconut fat or sucrose evaluations ((Cera et al., 1990; Buettner et al., 2006; Buettner et al., 2007; Amin et al., 2011; Cahova et al., 2012). These differences are probably due to the lowest amounts of fat and sucrose included simultaneously in present diet than all the prior individual studies. In addition, foodcalorie-body weight relation of present study is in accordance with other studies using rats under high calorie diets (Moura et al., 2012), with the significant increase of the sera glucose value in animal models under a diet with high saturated fat content (Cahova et al., 2012) and the registration of blood pressure was not done in the prior coconut or sucrose studies (Cera et al., 1990; Buettner et al., 2006; Buettner et al., 2007; Amin et al., 2011; Cahova et al., 2012). 


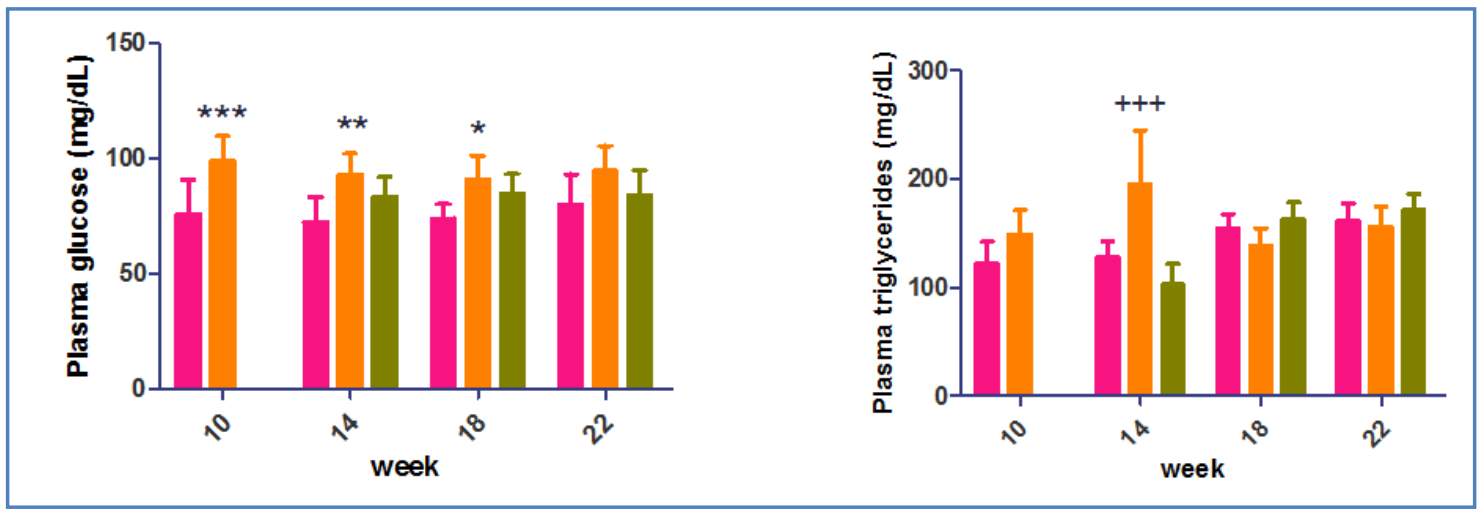

A

$\mathbf{B}$

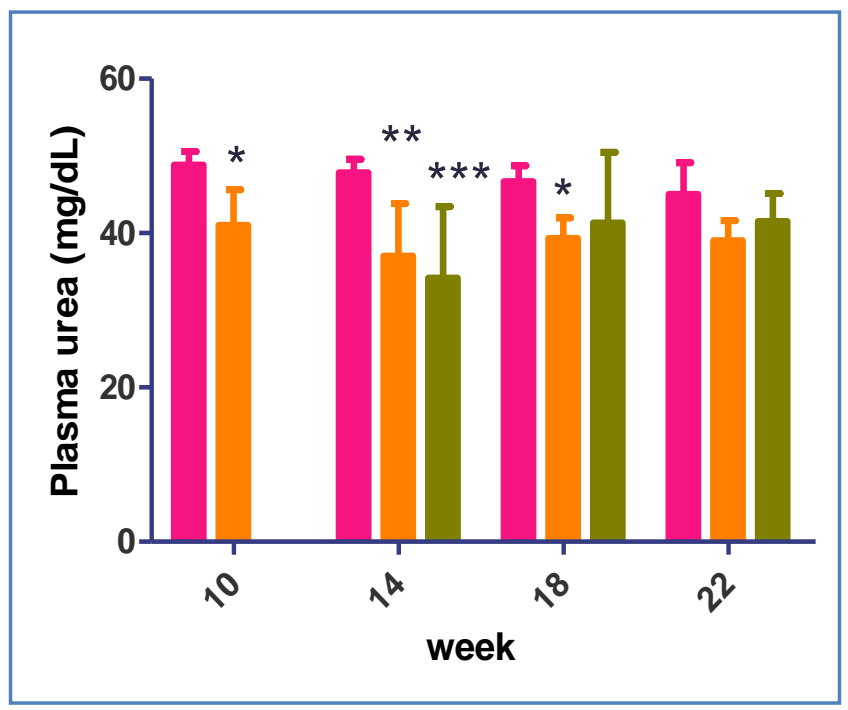

\section{C}

Figure 3 Biochemical values of the rat groups. The differences $(*),(* *)$ and $(* * *)$ had $\mathrm{P}$ values of $<0.05$ versus $\mathrm{S}$ group, $<0.01$ versus $\mathrm{S}$ group and $<0.001$ versus $S$ group, respectively (A and C). The difference $\left({ }^{+++}\right.$) had a P value of $<0.001$ versus the groups $S$ and $E$ (B).

Standard group (pink bar), experimental group (orange bar) and experimental plus aspartame group (brown bar).

Therefore, the increasing body weight of rats via high saturated fat in the E diet versus WHO/FAO values caused metabolic disorders such as impaired glycemia, high systolic blood pressure and hypertriglyceridemia in according with the information from overweight-obesity related diseases (Jia, 2015). However, all the metabolic changes in the $\mathrm{E}$ group returned to normal values probably due to the reduced amounts of fat and sucrose added in this experimental diet.

On the other hand, the rat group under the experimental diet plus aspartame intake had a consumption of this sweetener slightly greater than the accepted daily intake for humans (Magnuson et al., 2007).

The intake patterns of food and calories in the EA group are explained by the effects of the E diet as described above. However, the aspartame intake avoids the high body weight as observed in the E group. The weight loss by aspartame has been reported extensively (Ishii et al., 1981; Butchko et al., 2002; de la Hunty et al., 2006; Palmnäs et al., 2014). In this case, the reduction of the body mass cannot be explained by a significant loss of adipose tissue. Hence, the possible additional mechanism for the weight loss is through the reduction of muscle mass because the high body weight observed in the E group was not due to a significant increase of the adipose tissue and the plasma creatinine was only diminished in the EA group. It is important to note that the serum creatinine is a reliable marker for the evaluation of the muscle mass if the kidney function and dietary protein intake is undertaken as was done for the E versus EA data (Perrone et al., 1992; Patel et al., 2013). Changes in muscle mass or serum creatinine during loss of body weight due to aspartame were not evaluated previously (Ishii et al., 1981; Butchko et al., 2002; de la Hunty et al., 2006; Palmnäs et al., 2014). 


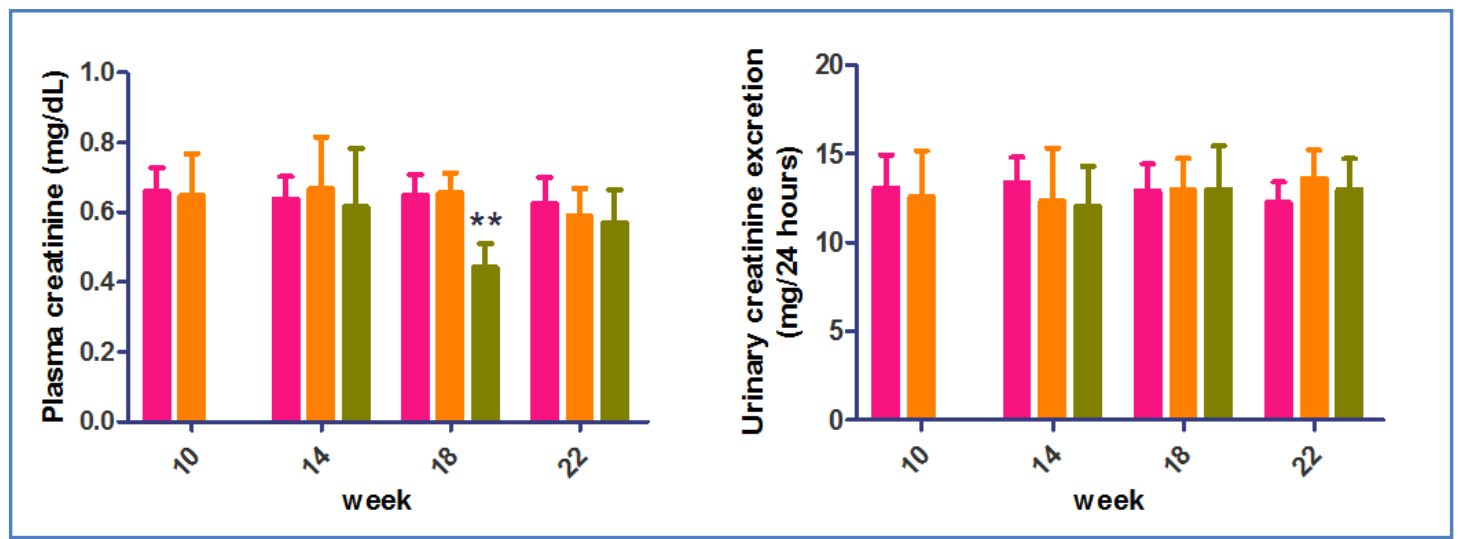

A

B

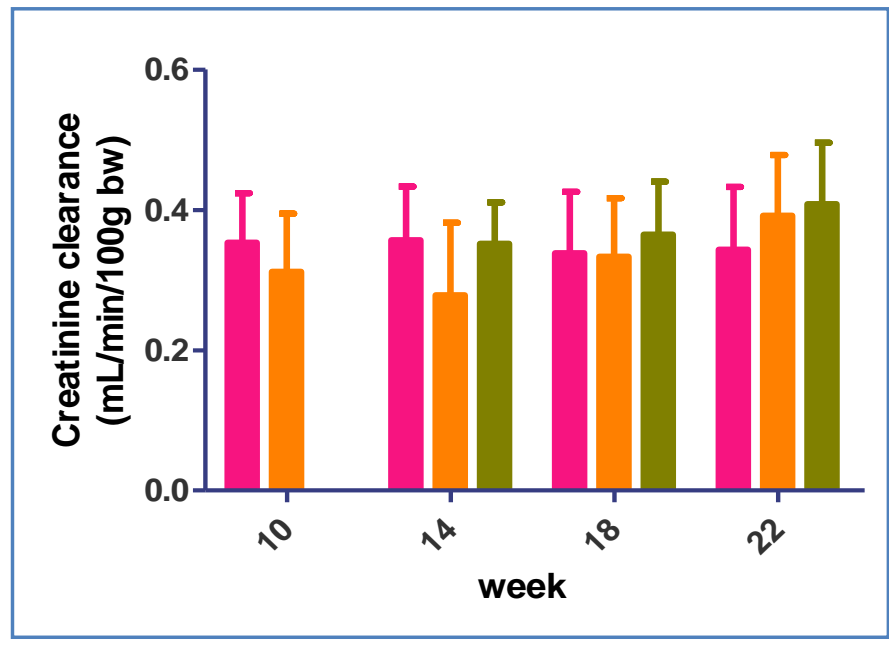

C

Figure 4 Creatinine results of the rat groups. The difference (**) had a P value of $<0.01$ versus the groups S and E (A). Plate B and C did not show significant changes. Standard group (pink bar), experimental group (orange bar) and experimental plus aspartame group (brown bar). bw; body weight.

The changes in the remainder of biochemical parameters (glucose, triglycerides and urea) due to the E diet were avoided or diminished by the aspartame ingestion in the EA group. Lipid outcome for the present study is in agreement with the failure of hypertriglyceridemia due to aspartame intake in humans following lipid loading (Magnuson et al., 2007).

Furthermore, glucose and urea changes by aspartame were not reported previously; however, all prior studies were conducted under different experimental designs (Butchko et al., 2002; Magnuson et al., 2007; Palmnäs et al., 2014). Finally, the consumption of aspartame by the rats under the E diet caused an early and prolonged increase of the blood pressure than the animals under water intake and the same $\mathrm{E}$ diet. This situation was probably caused by the presence of vasoactive substances came from the aspartame metabolism. The systemic hypertension due to aspartame was associated in prior human data (Butchko et al., 2002; Roberts, 2004; Roberts, 2008). Hence, this is the first experimental evidence of transient hypertension via aspartame in animals under a high saturated fat diet. All of data from the EA group suggest that the aspartame intake by adult rats under an unhealthy diet with respect to WHO/FAO values has a beneficial effect on cardiovascular risk factors such as overweight/obesity, raised blood glucose and raised blood triglycerides. However, these changes were accompanied by raised blood pressure which is the leading risk factor for cardiovascular diseases alongside reduced creatinine in plasma which is a risk factor for type 2 diabetes (WHO, 2011; Moon et al., 2013). In this manner, further studies are needed to increase the evidence of the aspartame effects under high fat feedings instead the 
commonly evaluations using normal diets, including diets with other sources and amounts of fat.

In summary, experimental diet used in present study have high saturated fat with respect to the WHO/FAO limit produces negative effects on cardiovascular risk factors of the rats while the aspartame intake under the experimental feeding has mixed effects on the cardiometabolic factors of the animals.

\section{Conflict of interest}

Authors would hereby like to declare that there is no conflict of interests that could possibly arise.

\section{Acknowledgements}

Othoniel Hugo Aragon-Martinez is a CONACyT-fellow. The authors thank Alicia Quintana for their technical assistance.

\section{References}

Abhilash M, Paul MV, Varghese MV, Nair RH (2011) Effect of long term intake of aspartame on antioxidant defense status in liver. Food and Chemical Toxicology 49:1203-1207. DOI: 10.1016/j.fct.2011.02.019.

Amin KA, Kamel HH, Abd Eltawab MA (2011) Protective effect of Garcinia against renal oxidative stress and biomarkers induced by high fat and sucrose diet. Lipids in Health and Disease 10:6. DOI: 10.1186/1476-511X-10-6.

Anton SD, Martin CK, Han H, Coulon S, Cefalu WT, Geiselman P, Williamson DA (2010) Effects of stevia, aspartame, and sucrose on food intake, satiety, and postprandial glucose and insulin levels. Appetite 55:37-43. DOI: 10.1016/j.appet.2010.03.009.

Aune D (2012) Soft drinks, aspartame, and the risk of cancer and cardiovascular disease. The American Journal of Clinical Nutrition 96:1249-1251. DOI: 10.3945/ajen.112.051417.

Buettner R, Parhofer KG, Woenckhaus M, Wrede CE, KunzSchughart LA, Schölmerich J, Bollheimer LC (2006) Defining high-fat-diet rat models: metabolic and molecular effects of different fat types. Journal of Molecular Endocrinology 36:485-501. DOI: 10.1677/jme.1.01909

Buettner R, Schölmerich J, Bollheimer LC (2007) High-fat diets: modeling the metabolic disorders of human obesity in rodents. Obesity (Silver Spring, Md.) 15:798-808. DOI: 10.1038/oby.2007.608

Butchko HH, Stargel WW, Comer CP, Mayhew DA, Benninger C, Blackburn GL, de Sonneville LM, Geha RS, Hertelendy Z, Koestner A, Leon AS, Liepa GU, McMartin KE, Mendenhall CL, Munro IC, Novotny EJ, Renwick AG, Schiffman SS, Schomer DL, Shaywitz BA, Spiers PA, Tephly TR, Thomas JA, Trefz FK (2002) Aspartame: review of safety.
Regulatory Toxicology and Pharmacology 35:S1-S93. DOI: 10.1006/rtph.2002.1542

Cahova M, Dankova H, Palenickova E, Papackova Z, Kazdova L (2012) The opposite effects of high-sucrose and high-fat diet on Fatty Acid oxidation and very low density lipoprotein secretion in rat model of metabolic syndrome. Journal of Nutrition and Metabolism 2012:757205. DOI: $10.1155 / 2012 / 757205$.

Cera KR, Mahan DC, Reinhart GA (1990) Evaluation of various extracted vegetable oils, roasted soybeans, mediumchain triglyceride and an animal-vegetable fat blend for postweaning swine. Journal of Animal Science 68:2756-2765. DOI: /1990.6892756x

Colagiuri S, Miller JJ, Edwards RA (1989) Metabolic effects of adding sucrose and aspartame to the diet of subjects with noninsulin-dependent diabetes mellitus. The American Journal of Clinical Nutrition 50:474-478.

de la Hunty A, Gibson S, Ashwell M (2006) A review of the effectiveness of aspartame in helping with weight control. Nutrition Bulletin 31:115-128. DOI: 10.1111/j.14673010.2006.00564.x

FAO (2010) Fats and fatty acids in human nutrition. Report of an expert consultation. FAO Food and Nutrition Paper No. 91. Rome: Food and Agriculture Organization of the United Nations, 2010.

Feijó F de M, Ballard CR, Foletto KC, Batista BA, Neves AM, Ribeiro MF, Bertoluci MC (2013) Saccharin and aspartame, compared with sucrose, induce greater weight gain in adult Wistar rats, at similar total caloric intake levels. Appetite 60:203-207. DOI: 10.1016/j.appet.2012.10.009.

Fisher H (1965) Variations in the urinary creatinine excretion of rats fed diets with different protein and amino acid content. The Journal of Nutrition 85:181-186.

Frey GH (1976) Use of aspartame by apparently healthy children and adolescents. Journal of Toxicology and Environmental Health 2:401-415. DOI: $10.1080 / 15287397609529442$

FSANZ (2004) Consumption of intense sweeteners in Australia and New Zealand: Benchmark Survey 2003. Food Standards Australia New Zealand. Ray Morgan Research, Report Series 8, Canberra.

Gombos K, Varjas T, Orsós Z, Polyák E, Peredi J, Varga Z, Nowrasteh G, Tettinger A, Mucsi G, Ember I (2007) The effect of aspartame administration on oncogene and suppressor gene expressions. In Vivo 21:89-92.

Gougeon R, Spidel M, Lee K, Field CJ (2004) Canadian diabetes association national nutrition committee technical 
review: Non-nutritive intense sweeteners in diabetes management. Canadian Journal of Diabetes 28:385-399.

Gupta V, Cochran C, Parker TF, Long DL, Ashby J, Gorman MA, Liepa GU (1989) Effect of aspartame on plasma amino acid profiles of diabetic patients with chronic renal failure. The American Journal of Clinical Nutrition 49:1302-1306.

Hazelhoff MH, Bulacio RP, Torres AM (2012) Gender related differences in kidney injury induced by mercury. International Journal of Molecular Sciences 13:10523-10536. DOI: 10.3390/ijms 130810523 .

Hosten AO (1990) BUN and Creatinine. In: Walker HK, Hall WD, Hurst JW (Eds) Clinical Methods: The History, Physical, and Laboratory Examinations. 3rd edition. Boston: Butterworths 874-878.

Ishii H, Koshimizu T, Usami S, Fujimoto T (1981) Toxicity of aspartame and its diketopiperazine for Wistar rats by dietary administration for 104 weeks. Toxicology 21:91-94. DOI: 10.1016/0300-483X(81)90119-0

Jia W (2015) Obesity in China: its characteristics, diagnostic criteria, and implications. Frontiers of Medicine 9:129-133. DOI 10.1007/s11684-015-0387-x

Johnson RK, Appel LJ, Brands M, Howard BV, Lefevre M, Lustig RH, Sacks F, Steffen LM, Wylie-Rosett J, American Heart Association Nutrition Committee of the Council on Nutrition, Physical Activity, and Metabolism and the Council on Epidemiology and Prevention (2009) Dietary sugars intake and cardiovascular health: a scientific statement from the American Heart Association. Circulation 120:1011-1020. DOI: 10.1161/CIRCULATIONAHA.109.192627.

Johnson-Delaney C (2008) Exotic companion medicine handbook for veterinarians. Florida: Zoological Education Network. ISBN 0-9636996-4-4.

Knopp RH, Brandt K, Arky RA (1976) Effects of aspartame in young persons during weight reduction. Journal of Toxicology and Environmental Health 2:417-428. DOI: $10.1080 / 15287397609529443$

López-Varela S, Sánchez-Muniz FJ, Cuesta C (1995) Decreased food efficiency ratio, growth retardation and changes in liver fatty acid composition in rats consuming thermally oxidized and polymerized sunflower oil used for frying. Food and Chemical Toxicology 33:181-189. DOI: 10.1016/0278-6915(94)00133-9

Magnuson BA, Burdock GA, Doull J, Kroes RM, Marsh GM, Pariza MW, Spencer PS, Waddell WJ, Walker R, Williams GM (2007) Aspartame: a safety evaluation based on current use levels, regulations, and toxicological and epidemiological studies. Critical Reviews in Toxicology 37:629-727. DOI: 10.1080/10408440701516184
Mexican Official Norm NOM-166-SSA1-1997 (1999) For the operation and organization of clinic laboratories. Official Journal of the Federation. México City, México.

Moon JS, Lee JE, Yoon JS (2013) Variation in serum creatinine level is correlated to risk of type 2 diabetes. Endocrinology and Metabolism (Seoul, Korea) 28:207-213. DOI: 10.3803/EnM.2013.28.3.207.

Moura LP, Figueredo GA, Bertolini NO, Ceccato M, Pereira JR, Sponton AC, de Mello MA (2012) Dietary restriction, caloric value and the accumulation of hepatic fat. Lipids in Health and Disease 11:2. DOI: 10.1186/1476-511X-11-2.

National Research Council (US) Committee for the Update of the Guide for the Care and Use of Laboratory Animals (2011) Guide for the Care and Use of Laboratory Animals. 8th edition. Washington (DC): National Academies Press (US).

Nettleton JA, Villalpando S, Cassani RS, Elmadfa I (2013) Health significance of fat quality in the diet. Annals of Nutrition \& Metabolism 63:96-102. DOI: 10.1159/000353207.

Olmsted F, Corcoran AC, Page IH (1951) Blood pressure in the unanesthetized rat. II. Spontaneous variations and effect of heat. Circulation 3:727-729. DOI: 10.1161/01.CIR.3.5.727

Palm M, Lundblad A (2005) Creatinine concentration in plasma from dog, rat, and mouse: a comparison of 3 different methods. Veterinary Clinical Pathology 34:232-236. DOI: 10.1111/j.1939-165X.2005.tb00046.x

Palmnäs MS, Cowan TE, Bomhof MR, Su J, Reimer RA, Vogel HJ, Hittel DS, Shearer J (2014) Low-dose aspartame consumption differentially affects gut microbiota-host metabolic interactions in the diet-induced obese rat. PLoS One 9:e109841. DOI: 10.1371/journal.pone.0109841.

Patel SS, Molnar MZ, Tayek JA, Ix JH, Noori N, Benner D, Heymsfield S, Kopple JD, Kovesdy CP, Kalantar-Zadeh K (2013) Serum creatinine as a marker of muscle mass in chronic kidney disease: results of a cross-sectional study and review of literature. Journal of Cachexia, Sarcopenia and Muscle 4:1929. DOI: 10.1007/s13539-012-0079-1.

Perrone RD, Madias NE, Levey AS (1992) Serum creatinine as an index of renal function: new insights into old concepts. Clinical Chemistry 38:1933-1953.

Poudyal H, Panchal SK, Ward LC, Waanders J, Brown L (2012) Chronic high-carbohydrate, high-fat feeding in rats induces reversible metabolic, cardiovascular, and liver changes. American Journal of Physiology. Endocrinology and Metabolism 302:E1472-E1482. DOI: 10.1152/ajpendo.00102.2012. 
Roberts HJ (2004) Aspartame disease: a possible cause for concomitant Graves' disease and pulmonary hypertension. Texas Heart Institute Journal 31:105.

Roberts HJ (2008) Overlooked aspartame-induced hypertension. Southern Medical Journal 101:969. DOI: 10.1097/SMJ.0b013e3181826e78.

Romestaing C, Piquet MA, Bedu E, Rouleau V, Dautresme M, Hourmand-Ollivier I, Filippi C, Duchamp C, Sibille B (2007) Long term highly saturated fat diet does not induce NASH in Wistar rats. Nutrition \& Metabolism 4:4. DOI: 10.1186/17437075-4-4

Schernhammer ES, Bertrand KA, Birmann BM, Sampson L, Willett WC, Feskanich D (2012) Consumption of artificial sweetener- and sugar-containing soda and risk of lymphoma and leukemia in men and women. The American Journal of Clinical Nutrition 96:1419-1428. DOI: 10.3945/ajcn.111.030833.

Shahangian S, Ash KO, Rollins DE (1984) Aspartame not a source of formate toxicity. Clinical Chemistry 30:1264-1265.

Soffritti M, Belpoggi F, Degli Esposti D, Lambertini L, Tibaldi E, Rigano A (2006) First experimental demonstration of the multipotential carcinogenic effects of aspartame administered in the feed to Sprague-Dawley rats. Environmental Health Perspectives 114:379-385. DOI: 10.1289/ehp.8711

Soffritti M, Belpoggi F, Tibaldi E, Esposti DD, Lauriola M (2007) Life-span exposure to low doses of aspartame beginning during prenatal life increases cancer effects in rats. Environmental Health Perspectives 115:1293-1297. DOI: 10.1289/ehp.10271
Stegink LD (1987) The aspartame story: a model for the clinical testing of a food additive. The American Journal of Clinical Nutrition 46:204-215.

Stegink LD, Brummel MC, Filer LJJr, Baker GL (1983) Blood methanol concentrations in one-year-old infants administered graded doses of aspartame. The Journal of Nutrition 113:16001606.

Thomas MA, Rice HB, Weinstock D, Corwin RL (2002) Effects of aging on food intake and body composition in rats. Physiology \& Behavior 76:487-500. DOI: 10.1016/S00319384(02)00800-4

WHO (2011) Global Atlas on Cardiovascular Disease Prevention and Control In: Mendis S, Puska P, Norrving B (Eds.) World Health Organization, Geneva.

WHO/FAO (2003) Diet, Nutrition and the Prevention of Chronic Diseases. Report of a Joint WHO/FAO Expert Consultation. WHO Technical Report Series No. 916. Geneva: World Health Organization, 2003.

WHO/FAO/UNU (2002) Protein and Amino acid Requirements in Human Nutrition. Report of a Joint WHO/FAO/UNU Expert Consultation. WHO Technical Report series No. 935. Geneva: World Health Organization.

Zulet MA, Barber A, Garcin H, Higueret P, Martínez JA (1999) Alterations in carbohydrate and lipid metabolism induced by a diet rich in coconut oil and cholesterol in a rat model. Journal of the American College of Nutrition 18:36-42. DOI: 10.1080/07315724.1999.10718825. 